\title{
Module Development of Introduction Accounting Based on Problem Solving
}

\author{
Revita Yuni*; Roza Thohiri \\ Medan State University, Indonesia \\ Email: revitayuni25@gmail.com
}

\begin{abstract}
In the early semester, every study program at faculty of economy required the student to take the introduction of accounting lectures. After taking the lecture the students are expected to be able to comprehend the basic concepts of accounting well. The financial reports material became one of the difficult material in the accounting lecture. Generally, the difficulty could be seen when the students were asked to shift the data from the worksheet to financial reports. It was because the students came from the different high school background. Therefore, it could be affect toward their comprehension of accounting. Because. Of that reason it was important to develop the material in form of module based problem solving, which can be used to help the students learn how to solve the problem that appears in their experience. This research was aimed to produce the valid module based problem solving.It used 4D module (four-D models). The development of four D consists of 4 phases. They are: 1) Define; 2) Design; 3) Develop; 4) Dessiminate. This development was only untill development phase while dessiminate phasewas not done. The subject of module based problem solving at introduction of accounting lectureswas the first year student of faculty of economy Medan state university. The criterion of the subject eksperimental was the condition of the student which was suitable with the researchers'need. The students haven't used the module based problem solving at the introduction of accounting lecture which is valid, practical, and effective. The module was valid to use because the result of the module validity development achieved $82.29 \%$ achievement level, and the module practicality achievement was $81.57 \%$, and it could be categorized practical in learning process. The level of students activity achievement from four categories that was researched in learning process was $63.95 \%$. It could be categorized as active students and module was categorized as an effective module. Therefore, the introductory accounting module based problem solving can be applied in learning process.
\end{abstract}

Keywords: Introductory Accounting Module; Problem Solving

\section{Introduction}

One of LPTK university's goal is to produce the profesional and highly competitive prospective educators. It can be achieved by two strategies. First,to increase the students' intelectual ability, and to lead to the broad-based educational goals, real benefit, and meaningful in preparing the students to face the challenge future. The learning quality could be seen from learning comprehension. That isfrom learning process. 
In order to achieve a learning objective which is the comprehensionofthe next accounting concepts, a knowledge of accounting basics is a main key to do the practice and theory easily. In fact, the education of accounting that have been taught in university was considered as a knowledge which oriented to mechanism theoritically. It was very different with the practice in the real workplace. This problem of course would complicate indeed confused the students to comprehend the basic concept of accounting itself. Therefore, the students' comprehension level toward the basic concept of accountingstill showed the unexpected result, which had a straight effect to learning process.

In the early semester, every study program at faculty of economy, required the students to take the introduction of accounting lecture. After taking it, the students were hoped to be able to comprehend the basic concept of accounting well. The financial report became one of the difficult material in accounting. Generally, the students' difficulty was showed when the students were asked to shift the data from the worksheet to the financial report. The another difficulty was also showed on students comprehension towards systematic financial statement. It was because the students of faculty of economy came from the different middle school background. Therefore, it affected to their comprehension of accounting itself. Based on these problems, the use of the module based problem solving was one of the alternative in solving those problems.

Problem solving is a troubleshooting method or a way of presenting the lesson by encouraging the students to find and solve the problems or issues in order to achieve learning objective. This method was created by an American named John Dewey. It was named problem method. Norwood (1995: 231) said that problem solving was defined as an individual process in using knowledge, skill, and comprehension which was gotten before to satisfy the demand from an unusual situasion. The students should synthesize something that had been learned, then applied it in a new and different situasion.

Problem solving can be used as an alternative learning approach which is inovative sinceit can optimize the process skill and increase the students'achievement. Arends (2008: 42) said that the teaching-based problem was a learning approach in order that the students developed the skill of problem solving, learnt adults' role and became independent students. By applying the module based problem solving, the students could be given the meaningful learning experience since it was developed to help the students learned how to solve the problem that occured in their experiences. The use of learning module based problem solving in developing this module was aimed to increase students' involvement actively in learning process. Moreover, the use of this module was aimed to increase students' competency toward the comprehension of material and be able to relate the problem based on their learning experience and learned independently without any facilitator.

It became a basic for researcher to do the development research with title " the development of module based problem solving". The purpose of this development was to produce the module based problem solving at introduction of accounting lecture, revealed the validity, partikality, and effectivity toward the module based problem solving.

\section{Methodology}

Based on the purpose of the research which to produce the valid, practical, and effective module based problem solving, so this research was a development research. According Putra (2012: 70) said that research and development was systematical study toward the complete scientific knowledge.

This research used four $D$ models. The development of it consisted of four main phase. They were: 1) Define; 2) Design; 3) Develop; 4) Dessiminate Thiangrajan in Trianto (2012: 184). This research 
was only until develop step while dessiminate was not done because of the limitation of energy, cost, and time.

The steps of module development were like this. The define phase was aimed to define the learning objectivecontained in the curriculum. This step consisted of two steps activity. They were curriculum analysis, concept analysis, and student analysis. The analysis of curricullum was done by analyzing SK and KD of the material in the sylabus. The analysis of the students was done in order to know the characteristic of students. It consisted of age, motivation, background, students' knowledge, academic ability, and social skill. It can influenced the development process that will be done.

In concept analysis, the identification and formulate the key concepts were done. They would be arranged in the material consisted in module based problem solving. Based on the indicator and learning objective, was applied the key concepts such as:

1. The definitation of accounting, accounting information user, and areas accounting specialization

2. Definition, components, and many kinds of financial reports

3. The definition of transaction, and transaction proof analysis.

4. The definition of accounting equation and arrange the accounting equation

5. General ledger

6. Ledger andtrial balance

7. Adjusting journal entry

8. Worksheet

9. Financial report

- Profit and loss

- Capital changes

- Balance sheet

- Cash flow

10. Closing entries and trial balance after closing

11. Accounting trading company

- Special journal

- Posting special journal to ledger.

- The cost of goods sold

12. Adjusting journal, worksheet, and financial report

13. Introduction to manufacturing company accounting

The design stage was aimed to design the module based problem solving which was completed by concept mapssuitable with SK and KD, and learning indicators which had been set. The module was designed in such a way so that enables the students to learn according to their own learning abilities. According to Sanjaya (2010: 331-332) said that the steps of arranging the module were: a) formulate the learning objectives specifically, structured, and mastered by the students after accomplishing the learning; b) a description of the material that the students is learning should match with objectives, SK, KD which want to achieve; c) the list of tools and materials were used by the students in learning-teaching process should match with students' learning experiences; d) the students' learning activities were arranged in form of reading texts and the direction to be followed; e) the evaluation's sheets to measure students' mastery degree toward the material being learnt with answer sheets; f) Key answer and evaluation. The 
design'step arranged the specification of the product that was being produced. The product specification design were:

\section{A. Cover Appearance}

Cover appearance was designed in such a way in order to attract students' attention to learn the contents. The colour combination of it was matched between the colour of the media pictures and the content.

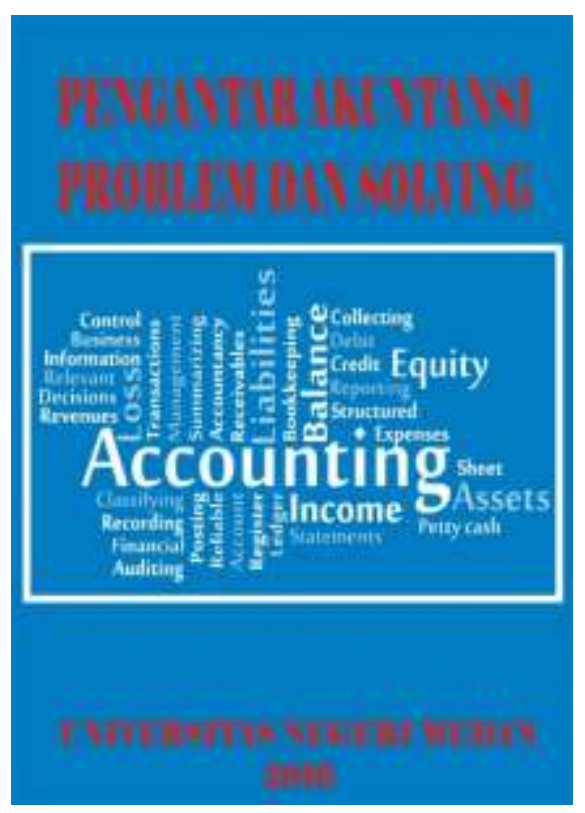

Fig. 1 Module cover design

\section{B. Formulation of the Learning Objectives}

The learning objectives were arranged more specific and systematic based on provision of curriculum. It started from setting competency standard, basic competencies and indicators of learning objectives. From indicators were formulated learning objectives that should be mastered by the students. Learning objectives of cognitive domain and psikomotors were formulated based on SK, KD and indicators that had been set in curriculum. The design of formulation of learning objectives can be seen on following picture. 


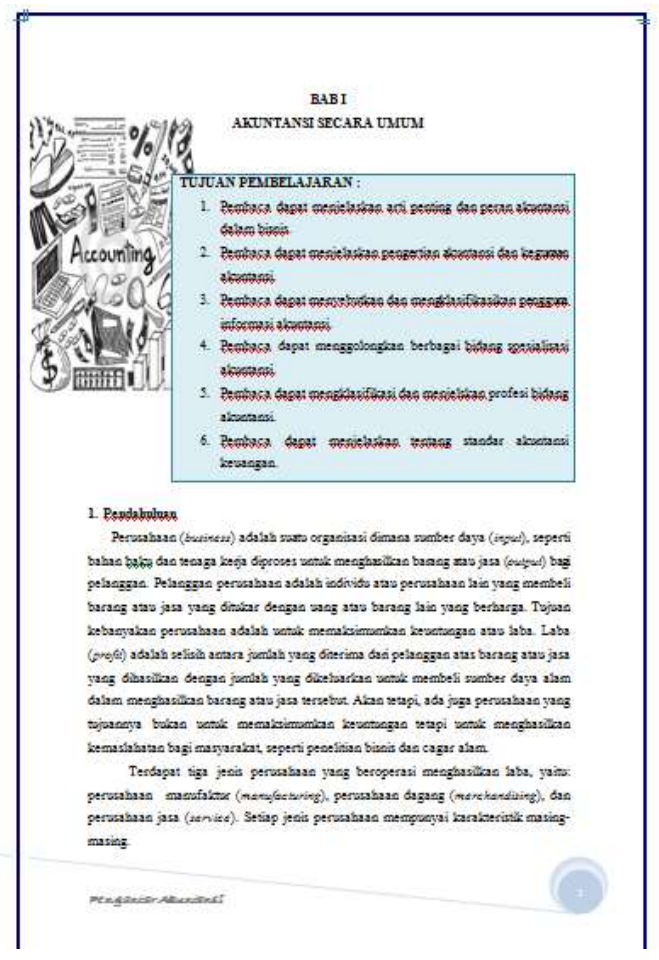

Fig. 2 Design of formulation of learning objectives

\section{Description of the Contents of the Learning Module}

The description of the contents of module refered to indonesia national qualification framework (KKNI). The curriculum that initially refered to achievement of competence to be referring to achievement of learning (learning outcome). In summary KKNI consists of 9 level of Indonesia human resources academic qualification.

The develop phase was aimed to produce the module based problem solving which was valid, practical, and effective. The develop phase consisted of expert validation and the test module based problem solving was done to know the validity, practicality, and effectivity of the module that was being developed. The arrranged module, then it was validated by two validators which consisted of an accounting expert and a linguist. The practicality assesment was done by the students. The practical modul was a module that can help the students in comprehending the material that had been developed. The effectivity of the module was seen by doing the test to see the learning outcome and the students' activity during the learning process.

\section{Result and Discussion The Module's Validity}

The expert's validationconsisted of two phases they are: 1) sheet validation, the sheet that the validators used to validate the module based problem solving; 2) the validation of the module by using validation sheet which had been revized and score given was to determine and revised the need that would be assesed in validating the module by validators. After the sheet of validation was revised and 
ready to use by expert so then modulevalidation was done. The module was validated by experts then they gave suggestion to revise. Next scoring to validation sheet by each validators.

Table 1 Result of scoring

\begin{tabular}{cccc}
\hline No. & Variable & $\begin{array}{c}\text { Degree of } \\
\text { achievement }(\%)\end{array}$ & Categorized \\
\hline 1 & Content & 82,86 & Valid \\
2 & Construct & 80 & Valid \\
3 & Language & 84,29 & Valid \\
4 & $\begin{array}{c}\text { Modul's } \\
\text { appearance }\end{array}$ & 82 & Valid \\
\hline & Average & 82,29 & Valid \\
\hline
\end{tabular}

The result of validators' scoring analysis on Table 1 consisted of 4 variables: 1) content with degree of achievement $82.86 \%$, it can be categorized as valid; 2) Construct with degree of achievement $80 \%$, it can be categorized as valid; 3) Language with degree of achievement $84.29 \%$, it can be categorized as valid; 4) modul's appearance with degree of achievement $82 \%$, it can be categorized as valid. Generally,the average module validity with degree of achievement $82.29 \%$ and module can be categorized as valid.

The validitas of moduleshowed to harmony, meaningfullness, and usability of the conclusion which had been made. The higher the validity of the product the better conclusion were taken, and better the level of meaningfullness indeks its usefulness. The variables of the module validity were content' validity, construct, language, and module's appearance.

The presentation of the module's material was valid because the material exposure was suitable with ability and students' need. The description of module contents were arranged systematically so that the users can understand the material easily. The module was formulated in one clear learning unit, start from material's presentation, instruction for use, and evaluation's tool. It based on the opinion of Yakin (2017) that the meaning of module is a learning material of instructional that is relatively short and specific content that is arranged to achieve the kearning objectives. The module usually has a wellcoordinated series of activities related tomaterial, media and evaluation.

The presentation of that module was suitable with students' ability. According to Nieveen in Subekti (2010) the validity of the product can be related to two things: 1) is the result of the development based on a strong theorytical rationale, and 2) is there consistency internally. On the other hand, the validity determination was determined by the experts or the persons who understand about the module.

\section{Praktikalitas Module}

Praktikalitas module based problem solving was asessed by the students class A reguler, the education of economy department which became the subject of the research all at once. After assessment of the practicality of module based problem solving by the students, then continued with analysis of the data. 
Table 2 Result of practicality by the students

\begin{tabular}{cccc}
\hline No. & Variabel & Tingkat pencapaian (\%) & Kategori \\
\hline 1 & Learnability & 83,52 & praktis \\
2 & Efficiency & 80,71 & praktis \\
3 & Effectiveness of time & 80,48 & praktis \\
\hline & Average & 81,57 & praktis \\
\hline
\end{tabular}

The module learnability that is the letter as an advisor in learning process with the grade $83.52 \%$ categorized that module based problem solving was practical for the user. Because module had instruction for use, the language that suitable with the student' characteristic, individual usability, and the exercises could help the lecturer in directing the students to understanding the concept. The module was designed in order to ease the lecturer in guiding the students in learning process.

The efficiency of the module for the students with grade $80.71 \%$ can be categorized practical because the module can help the students in explaining the concept of module practically and it is hoped that it is able to help the lecturer directing the students in learning process. According to the national department of education (2008: 5-6) one of the purpose of module was to clarify and ease the presentation of the message so that it was not too verbal. According to Sanjaya (2010:332) one of the purpose of the module was to increase the effectivity and efficiency of the learning and education objectives achievement.

The module is practical in effectiveness of time with the grade $80.48 \%$ authorized that module based problem solving is practical. It is practical to use by the lecturer to guide the students in learning process. The practicality of module proved that 37 students who used the module based problem solving in learning process $86.04 \%$ students were complete. According to Sukardi (2011: 2) said that the evaluationwas used to get the information about the students' activity and then it was used to assess the level of implementation of the programthat had been planned.

From the result of the evaluation, based on the theory that had been stated, the learning process was effective because more than $85 \%$ the students were complete. The evaluationserved to determine wheter the students have already had the competency that had been set so that they were feasible to be given the next learning programme (Sanjaya., 32: 2010). It means that class was feasible to follow the next learning programme.

So that, the lecturer can make use of the minimal time to maksimal time. According to national ministry of education (2008b: 5) the good module can solve the limitation of time, space and sense power for lecturer or advisor in learning process.

\section{Effectivity of Module}

The assessment of effectivity had a function to see the effectivity of module which was used in learning process. To get the result of effectivity of the module based problem solving, the observation of students' activities was done during learning process and learning outcomes. The average of students' activities from each category in four times meetings generally could be seen in Table 3. 
Table 3 Result of the degree of student' activities achievement

\begin{tabular}{|c|c|c|c|}
\hline No. & Students' Activities & $\% \mathrm{DP}$ & Criteria \\
\hline 1 & $\begin{array}{l}\text { Reading modules and } \\
\text { working on Exercises }\end{array}$ & 100 & Active once \\
\hline 2 & $\begin{array}{l}\text { Students ask questions } \\
\text { while following the } \\
\text { lesson }\end{array}$ & 53.49 & Quite active \\
\hline 3 & $\begin{array}{l}\text { Answering questions } \\
\text { from lecturers as well as } \\
\text { from other students }\end{array}$ & 63.95 & Active \\
\hline \multirow[t]{2}{*}{4} & Completing the task & 100 & Active once \\
\hline & Average & 79.36 & Active \\
\hline
\end{tabular}

Based on the table above, generally the students were active in lecture. The students could finish the assignment fastly and correctly because the direction in module was easy to understand by the students. It was like Uya's opinion (2014) stated that subjects could understand the problem from a question quickly and appropiately. Subjects were able to estimate precisely the problem solving strategies so that the subject could solve the problem well.

It could be said that the module based problem solving was effective to use in lecture, and it can increase the activities and motivation of the student during the class. The feeling of involvement which based on the motivation and high interest of the students in following the learning process in the class was the indikator of the quality process.

\section{Conclusion}

From the data description and the discussion above, it can be concluded that:

1. The module based problem solving had been made on introduction of accounting which was valid, practical, and effective..

2. The validity was $82.29 \%$ and module could be categorized valid. The practicality of the module by the students was $81.57 \%$ and module could be categorized practical in learning process. The degree of students' activities from four categories which had been observed in learning process was $63.95 \%$ it could be categorized that the students were active and module was effective.

\section{References}

Arend. RI. (2008). Learning to Teach. Penerjemah: Helly Prajitno Setjipto \& Sri Moelyantini Seotjipto. Yogyakarta: Pustaka Pelajar.

Caprioara, D. (2015). Problem Solving Purposea Means of Learning Mathematics in School. Romania Journal of Social and Behavioral Science University of Ovidius Constanta, 191: 1859-1864. 
H. Ulya, Kartono, A.Retnoningsih. (2014). Analysis of Mathematics Problem Solving Ability of Junior High School Students Viewed from Students' Cognitive Style. Journal of Education and Practice, 2(10).

Norwood. KS. (1995). The Effects of The Use of Problem Solving and Cooperative Learning on The Mathematics Achievement of Underprepared College Freshmen. PRIMUS, 5(3): 229-252.

Putra, Nusa. (2012). Reseach \& Development Penelitian dan Pengembangan: Suatu Pengantar. Jakarta: Rajawali Press.

Sanjaya, Wina. (2010). Kurikulum dan Pembelajaran, Teori dan Praktek Pengembangan KTSP. Jakarta: Kencana.

Saragih , A. Hasan. (2008). Kompetensi Minimal Seorang Guru Dalam Mengajar. Jurnal Tabularasa PPS UNIMED, 5(1): Juni 2008.

Subekti, Hasan. (2010). Pengembangan Perangkat Pembelajaran Sains SMP Berorientasi Pendidikan Berkarakter Dengan Model Kooperatif Pada Materi Sensitifitas Indera Peraba. (Jurnal). FMIPA. UNESA.

Sukardi. (2011). Evaluasi Pendidikan, Prinsip \& Operasionalnya. Jakarta: Bumi Aksara.

Tim Kementrian Pendidikan Nasional.(2008a). Penulisan Modul. Jakarta: Kemendiknas

Tim Kementrian Pendidikan Nasional. (2008b). Penulisan Modul. Jakarta: Kemendiknas

Trianto. (2012). Mendesain Model Pembelajaran Inovatis-Progresisf. Jakarta: Kencana.

Yakin Niat Telaumbanua, Bornok Sinaga, Mukhtar, Edy Surya. (2017). Development of Mathematics Module Based on Metacognitive Strategy in Improving Students' Mathematical Problem Solving Ability at High School. Journal of Education and Practice, 8(19).

\section{Copyrights}

Copyright for this article is retained by the author(s), with first publication rights granted to the journal.

This is an open-access article distributed under the terms and conditions of the Creative Commons Attribution license (http://creativecommons.org/licenses/by/4.0/). 